\title{
"THAT WAS A JOKE, YOU SHOULD LAUGH!" TOUR GUIDES AND THE PERFORMANCE OF HISTORY IN BUDAPEST, HUNGARY
}

KRISTINA UZELAC

32100 Vinkovci, Andrije Kačića Miošića 84a

Croatia

SAIFULLAH NASAR

87300 Quetta, Agha Siraj Villa 33, Arbab

Pakistan

MACARIO B. LACBAWAN JR.

Goethe University Frankfurt

Campus Bockenheim

60486 Frankfurt am Main, Gräfstr. 78,

Juridicum Postfach 104

Germany
DOI: $10.17234 /$ SEC.27.7

Original scientific paper /

Izvorni znanstveni rad

Received / Primljeno: 1 May 2015

Accepted / Prihvaćeno: 11 August 2015

The turn to performativity in the social sciences has spawned a new wave of scholarship that considers tourism as a performative process. However, the manner through which scholars understand tourism as performative drama is limiting. A fundamental critique of dramaturgy stems from its inability to account for performance as a chain of emergent social processes. Using the case of free walking tours in Budapest, Hungary, we argue that treating tourism as a performance is an act of fusion that culls its technique by deploying dominant cultural codes, materiality and humor. Performance hinges on an attempt to fuse various elements in a dramatic presentation. These elements include the (1) unsettling presence of the audience's feedback, (2) the lingering memory of previous performances, (3) the deployment of cultural codes, (4) the mundanity of the material means of symbolic presentation, and (5) the use of linguistic play through humor. We conclude this essay by elaborating other dimensions that could possibly open up more discussions on tourism as a performative phenomenon.

Keywords: Performativity, dramaturgy, memory, humor, materiality, walking tour, Budapest

\section{INTRODUCTION}

The tour guide asks us to form a semi-circle around him as he begins his story while regularly requesting that everyone huddle together - almost to the point of cuddling. It is a cold and windy morning in January but he 
does not seem to mind the weather as he narrates Hungarian history: from the migration of proto-Hungarians, the Turks who brought public baths, paprika and his name - Zoltan, the Habsburg, the Germans, the Russians, the fall of the Iron Curtain, present-day Hungary and his utopian rendition of a perfect country. It is a history condensed in one paragraph and delivered with an accompanying sigh, shrilled laughter, the flinching of eyebrows, a perfectly modulated voice and a facial expression that morphs every second. He closes his eyes while emphasizing the Holocaust and even moves his closed fists to his heart. At some point, he comes across as an excited clown, overly jumpy and thrilled to tell the story of how Hungary benefited from these events with special emphasis on how he relishes goulash and the Turkish baths where "...the snow touches and melts in the water. Aaahhh, how beautiful!” (Figure 1).

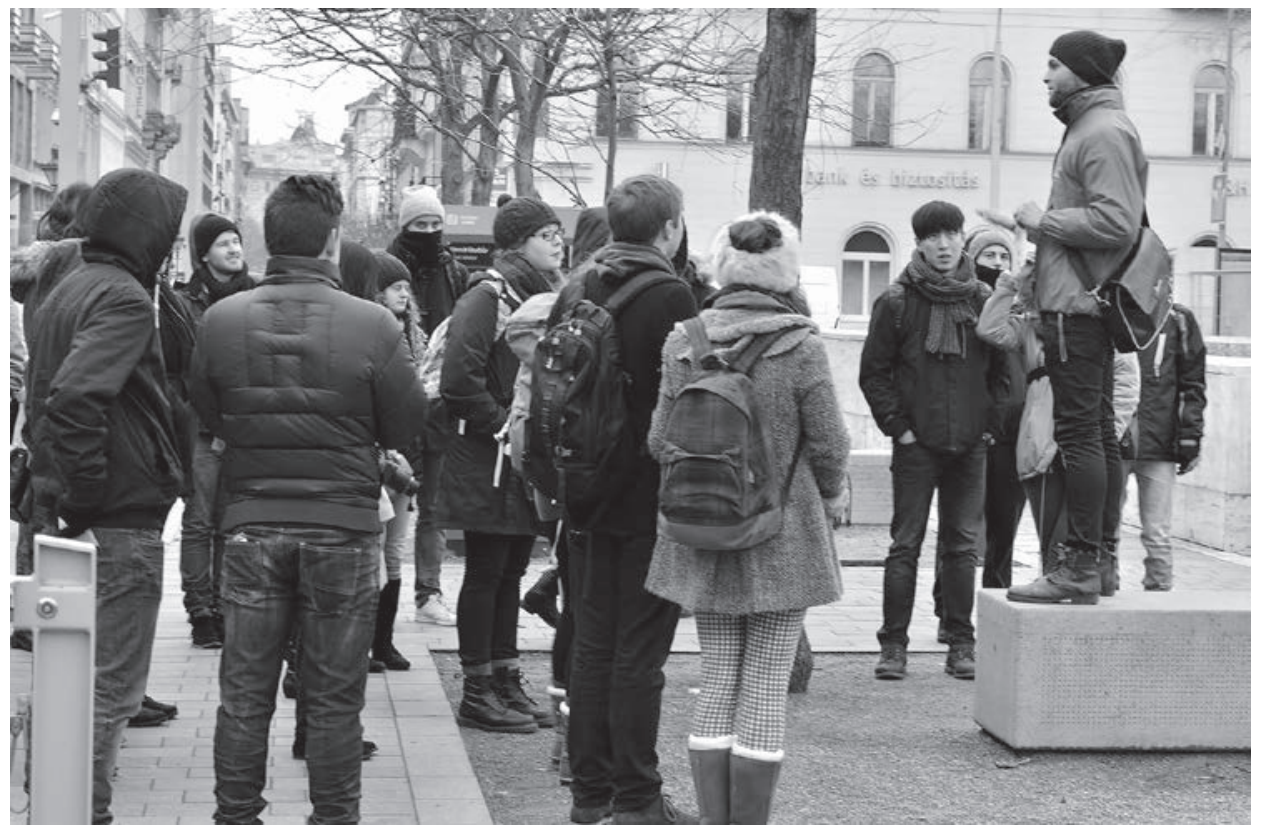

Figure 1: General Walk with Zoltan. Photo by Macario B. Lacbawan Jr., March 2015

At first glance, this could either be an account of a theatrical production or a grandfather who reminisces about the past at the twilight of his life. However, this is a description of a tour guide conducting a walking- 
tour that we attended as part of our research on tourism. At first, the tour appears very informal - a well-paid job for young enthusiastic people who are interested in sharing their stories about the city. However, as will be shown in the text, this natural informality is scripted and well-rehearsed. The three-hour tour represents a mesh of personal stories and scripts that are acted-out or performed in a space of interaction with tourists. In the following discussions, we sketch out how tourism is mediated by different forms of performance. First, we call attention to how the recent turn to performativity is hampered by the blind importation of dramaturgical analysis into tourism studies. Next, we outline how certain inadequacies in Goffman's work could be ameliorated by foregrounding walking-tours as performative attempts to fuse diverging elements into one coherent whole. Towards the end of this paper, we discuss other dimensions that could open up further discussions on performative tourism.

\section{SURVEYING THE STAGE}

There are three different free walking tour companies in Budapest. They are recognizable by their different meeting points (Deák Ferenc Square or Vörösmarty Square) and the color of the thin anoraks or signs worn by their guides (red or blue). We decided to join the tours conducted by blue guides that depart from Vörösmarty Square. The official name of the company is the Budapest Free Walking Tour and it employs around 20-25 guides. They offer five (5) different types of tours - a General Walk, Communism Walk, Jewish District Walk, Private Tours and the Ruin Pub Tour. During our two-month fieldwork, we participated in seven tours and become acquainted with seven tour guides (Angelika, Anna/Nusi, Judit, Zoltan, Norbert, Agy, Aron, and Orsi). Apart from joining the tours, our analysis is also based on two recorded semi-structured interviews with Judit and Angelika, Angelika's script, photographs and informal conversations with tourists and guides (Figure 2). 


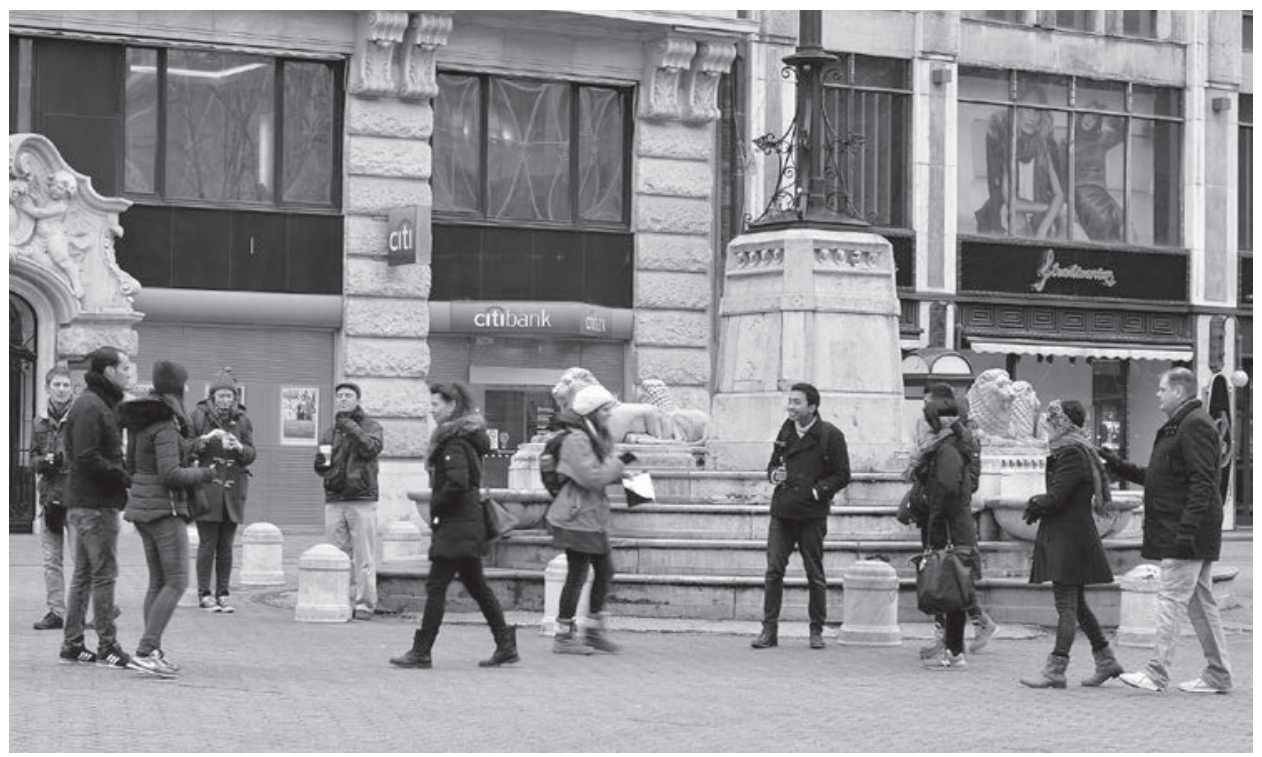

Figure 2: Meeting point at Vörösmarty Square.

Photo by Macario B. Lacbawan Jr., March 2015

The company's official script prescribes the main topics, jokes and sites that should not be omitted during the walk. Every tour starts at the small Vörösmarty Square near the river Danube. From the fountain in the northern part of the square, the general and communism tours continue towards Erzsébet Square (via the Danube promenade and Szabadság Square) and St. István Basilica from where they continue to the direction of Liberty Square (Communism Walk) and Charlie Statue (a Hungarian police officer) in Zríny Street (General Walk). The Jewish District Walk takes the opposite direction towards the Seventh District across Váci Street to the Dohány Synagogue. The main sites in this walk are synagogues and it ends, as is the case with the Communism Walk, in one of the ruin pubs (Instant or Szimpla Bar), while the General Walk finishes in the basement of the Hilton Hotel (on the Buda side).

\section{A FAILED AGENDA}

Given the publication of Jonathan Culler's programmatic article on tourism as an active form of signification in the 1980s (Culler 1981) and the innovative analysis of Judith Adler (1989) on the unfolding of travel as 
a performative art, it is rather odd to encounter a plea in the maiden issue of Tourist Studies for an analytic foregrounding of tourism within the rubric of "new" theoretical frameworks such as performance studies (Franklin and Crang 2001). Similarly, in 2007, the conference proceeding of Britain's Association of Social Anthropologists (ASA) issued an uncondescending evaluation of the discipline. ASA claims that the study of tourism has failed to join the bandwagon of certain iconic turns in social theory materiality, actor-network theory, and performativity (ASA 2007). Yet, as with other efforts to introduce new analytical directions in social analysis, ASA's envisioned path is simply a conceptual rendition and retrofitting of one framework into the analytic universe of tourism scholarship. More specifically, the importation of such works as dramaturgy (Goffman 1959) could pose serious risks because of its proclivity to straightjacket tourist performances as synonymous to a Goffmanesque reality, a world that is populated by thespians reciting scripts in a fleeting moment where they can easily enter and leave, as they prefer.

How then might we consider performative tourism? In this short paper, enumerating the drawbacks to the ASA's agenda will suffice, by focusing on the nature of performance in Goffman's dramaturgy. Towards the end of this section, we will sketch out our alternative approach by situating performative tourism as an act of fusion that culls its technique by deploying dominant cultural codes, materiality and humor. A fundamental critique of dramaturgy stems from its inability to account for performance as a chain of emergent social processes (Alexander, Giessen and Mast 2006). Such a conceptual loophole is apparent in how Goffman's metaphor of theater conjures-up an image of social action that only transpires on stage but easily ceases as the performance ends (Langer 2004). Even recent works that have taken dramaturgy as a framework fail to recognize this drawback, although they have implicitly provided a more nuanced account than Goffman's theatrical universe.

An enlightening analysis of tourism as a performance by Tim Edensor (2001) produces a complex typology of roles that are imputed when people start to travel, but never explicitly recognized the failure in Goffman's framework to account for the continuity of performance - beyond the stage! Part of his failure to recognize this inherent weakness results from how he neatly divides 
the tourist world up between stages of reflexivity and habit. Edensor contends that Goffman's stage depends on the active and reflexive individual and leaves no room for "unreflexive, habitual and unintentional enactions" (60). By foregrounding habitus (Bourdieu 1984) to articulate the instinctive and prereflexive dimension of tourist performance, Edensor (2001) has unfortunately reinforced the separation of performative stages that are inherent in Goffman's metaphor of a theater. Performance becomes bifurcated into separate islands and never construed as a continuum, a never-ending process of "transformation, enactment, being, negotiation and efficiency" (Harwood and El-Manstrly 2012: 16) that is too complex to pin by simply dividing performative tourism into habitual and non-habitual universes. After all, as tourism becomes part of a world that resembles an ethnoscape (Appadurai 1990) or an entity where time and space are annihilated by easy movement (Harvey 1990), such binary approaches are rendered moot by an increasing focus on examining tourism as a mundane everyday practice.

To reiterate, in a Goffmanesque universe, the actor dwells in a Manichean and Sardonic world, a life of discrete and multiple theaters. Thus far, this conception fails to recognize that performance is not simply the acting-out of a predetermined script that is crafted behind the scene and without the audience. Instead, performance hinges on an attempt to fuse various elements from different horizons of meaning (Gadamer 1993) in a dramatic presentation. These elements include the (1) unsettling presence of audience feedback, (2) the lingering memory of previous performances, (3) the deployment of cultural codes, (4) the mundanity of the material means of symbolic presentation, and (5) the use of linguistic play through humor. The performer leaves the stage and goes home while he revisits his scripts and curses his unreceptive audience. The following day, he entertains with an edited story, leaves, and again curses and rests... ad infinitum.

\section{FUSING CULTURE AND ACTION}

The effectiveness of tourist performances could be ascertained through the successful attempt of tour guides to hide the pre-scripted nature of their performance by fusing their presentation with the cultural horizon and psychological "state" of the tourists. The end-product of this would be a 
pragmatic co-translation of the guides' and tourists' respective "horizons of meaning" into one. As we have mentioned earlier in this essay, accounting for fusion in dramaturgical analysis fails to elucidate the extension of the cultural horizon as it presupposes a break between succeeding performances. Yet, what fusion necessitates is the possibility of extending and commingling of the symbolic worlds of tourist sites and the cultural horizon of their spectators. In this essay, we differentiate internal from external domestication as two forms of performative extension. Briefly, the former signifies how guides try to narrate history by telling stories of specific events in the past that significantly altered their lives. External domestication, on the other hand, describes how guides try to draw parallels between Hungary's culture and the tourist's country of origin by simultaneously breaking the borders of the local, national and transnational (Lofgren 1999:8). When properly executed, these two forms of extension could elicit psychological identifications from the tourists (e.g. crying tourists on the Jewish Walk).

Aside from internal and external domestication, there are two other crucial elements used to eliminate the artificiality of tours: employing mementoes and space as material pieces of evidence and creative linguistic play using humor. In dramaturgical analysis, the materiality of everyday presentation is absent while the physicality of theater is rendered mute and leaves no impact on the unfolding of the drama. On a side note, such inadequacy is expected in Goffman's emphasis on the symbolic play of roles and meanings. However, objects mediate symbols by providing an accompanying sensual and corporeal experience to a performance (Bartmanski and Alexander 2011). In this way, telling stories about distant events are embedded in objects and icons (Peirce 1998) that serve as a tangible index to the past. They become the physical embodiments of memory that bridge the act of remembrance to a story that has taken place centuries ago. Apart from the use of memorabilia, humor too provides an indivisible role in breaking the pre-scripted nature of tour guiding. When tour guides crack jokes, not only do they break the one-way flow of narration but they also creatively expand their presence and constantly draw the tourists' attention into the performance.

All in all, together with the active deployment of humor and memorabilia, the process of domesticating past events forms part of the 
compendium of the guides' performative techniques. In general, we argue that tourism is a performance that attempts at fusing conflicting cultural horizons of tourists with the histories and narratives of the host community. Such a performance strives to hide its pre-scripted dramatization of history by presenting a naturally emergent and contingent rendering of past events. In the following paragraphs, we illustrate how performance mediates tourism by examining the various techniques of tourist guides in presenting Budapest's tourist sites. We suggest that for a successful performance or fusion to take place, tour guides have to personalize history by invoking snippets of their lives that are affected by history. In this way, what emerges is not a plain touristic remembrance of things from a distant past but a spectacle (Debord 1994) where tourists witness the domestication and outright simulation (Baudrillard 1994) of history.

\section{EXTENDING AND RE-FUSING HORIZONS}

In the ephemeral interaction between tour guides and tourists, the former's performance is always prone to contestation. Such fleeting contact imposes on them (guides) the difficult task of narrating a script and relaying stories without giving space for ambiguity. That is, to guide tourists into the labyrinth of Budapest's history, their performance has to be authentic, spontaneous, politically sensitive, and at the same entertaining. Hence the tour company's slogan - infotainment! "My job is not to make them [tourists] cry... it is about entertainment and learning something at the same time, it's not about crying," says Angelika when describing the aims of the tour. The tour guides put a successful performance together by bringing disparate elements of the tour into a harmonious whole, as if the whole process is a stream in which all components are indistinguishable and inseparable from one other, where the entire performance appears to unfold spontaneously beyond time and space.

There are multifarious elements that must be fused with the preexisting scripts of a tour. These include guides, tourists as audiences who have different positionalities (e.g. age, gender, nationality, religious affiliation) each embodying a sense of history situated in different horizons, tourists sites (e.g. churches, synagogues, bridges, statues, cuisine), and 
Budapest's narrative that either diverges or converges with the historical memory of tourists. To assemble and fuse these elements as one, tourist guides foreground their performance through cultural extension and psychological identification (Alexander, Giessen and Mast 2006).

Cultural extension is achieved in two ways, namely external and internal domestication. The script written by the tour guides is decoded by the tourists when narrated. For a successful performance to unfold, the audience are supposed to feel the narration is relevant, personalized and known to them. The tour guides therefore adjust the content of their narration according to the profile of their audience. In this way, the process of domesticating externalities is accomplished by fusing the domesticated memory or history of Hungary with the "external" identities of tourists. For instance, tour guides regularly emphasize common cultural scripts such as the similarities between Hungarian and Turkish cuisine when they discuss the "positive" influence of the Ottoman invasion. Paprika is always highlighted as an integral spice of Hungarian cuisine in front of Turkish tourists. They often highlight that they are indebted to Turkey for introducing paprika and thermal baths to Hungarian culture. This a bid to domesticate tours for Turkish tourists. On the other hand, external domestication is accomplished differently depending on the nature of the tour and the historical baggage associated with specific events. On the General Tour, guides try to narrate the Holocaust without dwelling too much on the atrocities because the goal is to entertain the tourists. The dynamics, however, change on the Jewish and Communism Walks as these events define the scripts of the tour. To ameliorate this dilemma, the atrocities committed by the Austro-Hungarian empire and Ottoman Empire are never mentioned in historical narrations in front of Austrian and Turkish tourists (Figure 3).

External domestication also functions to regulate the content of performance. For instance, the tour guides' narration deliberately leaves out the history of Hungary with its neighbors such as Romania, Croatia ${ }^{1}$ and

\footnotetext{
${ }^{1}$ This issue of positionality also appeared at the beginning of one interview when the guide asked a Croatian colleague for their opinion on Croatian - Hungarian historical relations and the role of ban Josip Jelačić who is depicted as a hero in the popular Croatian national imaginary, and as an enemy in the Hungarian one. The guide said she wanted to be sure on how to adjust her further narration of these events.
} 


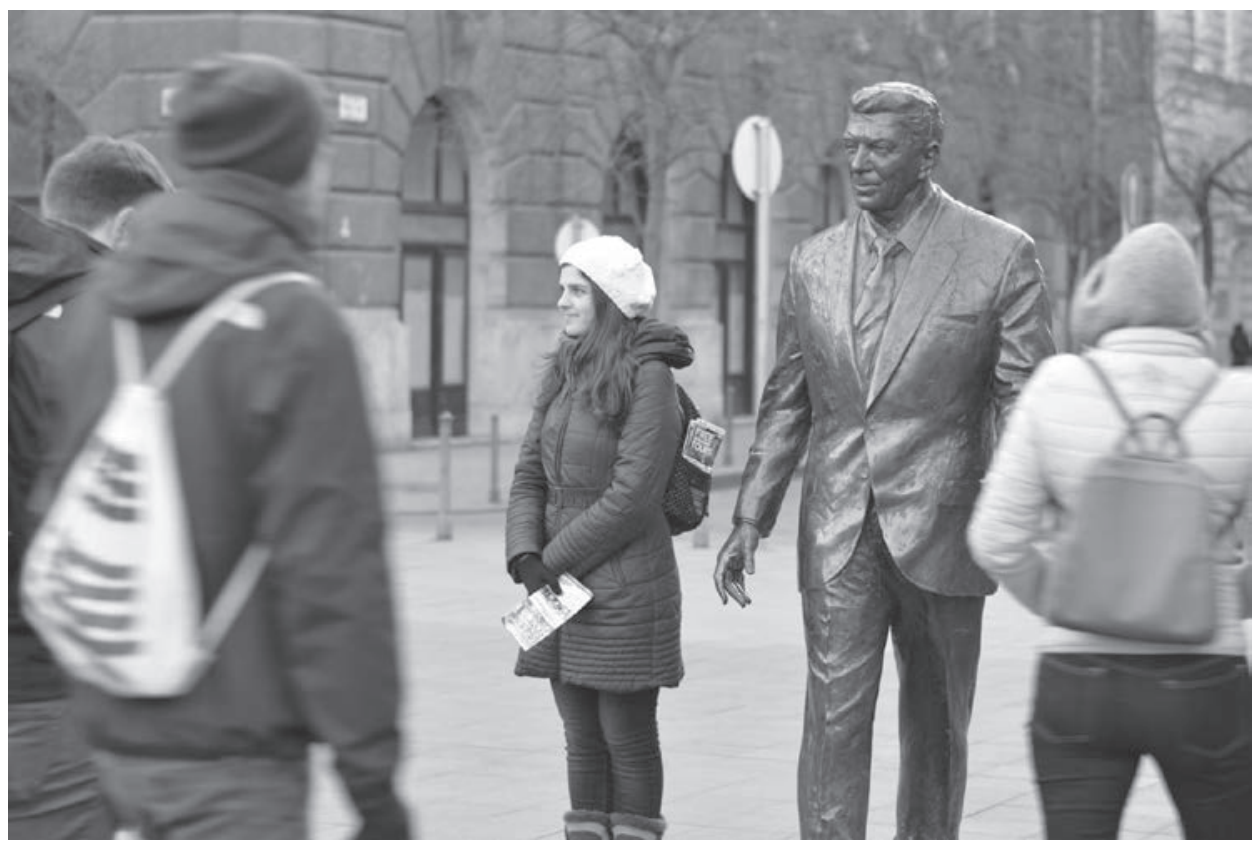

Figure 3: Jewish District Walk with Angelika and Judit.

Photo by Saifullah Nasar, March 2015

others in order to avoid potentially sensitive historical discussions. External domestication occurs when the tour is adapted to the taste or interest of tourists according to gender and age. Based on the tour guides' experiences, elderly people are keener to learn more about the history of Budapest while younger tourists prefer to have a "good time" in Budapest. "If there are many elderly people I talk more about history, culture and architecture. But I always look at their responses, because not all the older people are interested in history" says a tour guide. Conversely, guides will talk more about bars, cheap restaurants, and famous clubs if the group has younger tourists. Likewise, if the tour is composed mostly of female tourists, they provide more information about Hungarian wines and shopping. If there are more male tourists in the group, they place more emphasis on liquors and the city's night life. This is how the tour is customized according to the tourist profiles.

In tours that could induce strong emotional responses, such as the Jewish and Communism Walk, the guides try to personalize memory 
(internal domestication), so as to lend a layer of authenticity to their performance. They, for example, recount their relatives' tragic experiences of the Holocaust and communism to produce an identification with the tourists on a psychological and personal level. The effects of such a performance are very dramatic: it muddles the boundary between the audience and the narrator as it conceals the artificiality of the narration. The tour guide becomes not simply a worker for a travel agency but a living embodiment of history and a witness to how distant events in the past can impact personal lives in the present. It is the personalization or customization of the tours on another level - emotional, psychological and even visceral. What is said is felt and experienced by an ordinary individual. This attempt at portraying the ordinariness of the past facilitates fusion as tourists interact with a person whose life has been significantly altered by history.

The boundary between script, narrator and listeners must be eliminated in order to generate a successful performance. All should be done to touch the tourists. Otherwise, the audience may lose interest and even criticize the content, “...once when I said Soviet Russia, a Russian girl was really angry with me... why do I say that", says Angelica when discussing her occasional confrontations with tourists on the Communism Walk. On another occasion, she "was mentioning the Nazi's and the lady was angry with [her] -why didn't [she] say Germans, or Nazi Germans, because it was Germans who killed her grandfather". However, the tour guides also re-fuse elements of their performance if they fail. After a confrontation with a Russian tourist, Angelika tried to mollify her: "I tried to talk with her in person while walking, not in public, but in person. And I tried to understand her point of view". On other occasions,

"if I see uninterested or annoying expressions I try to speak as little. I ask them if they have a question, story to tell, or information to share or if they have a comment, or I ask them if everything is OK."

Clearly, the guide manages ambiguity from an uncompromising tourist gaze (Urry 1990) by bringing her performance closer to the person through private conversation. In this way, the possibility of a "breach" (Garfinkel 1967) in performance is managed and controlled efficiently. 


\section{MISE-EN-SCENE: THE ANATOMY OF HUMOR}

There are other ways to entertain the tourists and make the scripted tour more spontaneous and to re-fuse the performance if the tourists appear uninterested. Cracking jokes is one of the means available to the tour guides in this regard. Though jokes are scripted, they are delivered in a manner that makes them appear spontaneous. At the beginning of each tour, the guides ask the tourists to gather around them in a semi-circle and introduce themselves by making fun of their (Hungarian) names or by asking the tourist if they find the Hungarian language "interesting", "funny", "weird" or "difficult". In one tour session, Zoltan introduces his fellow guide by playing with cultural codes that are tapped from popular culture: "My colleague name is Agi. She would help me all the way. You know Maggi (famous noodle brand) - which children eat. You can call me Agi or Magi. It is OK." All the tourists laughed. It helps the tour guides in attracting the attention of the tourist before they reveal the itinerary of the tour.

Jokes are cracked in every single spot where the tour stops. They are told about historical monuments, Hungarian politicians, statues, the Hungarian language, etc. For instance, they make jokes about the Kiskirálylány (Little Princess) statue, situated along the Danube promenade sitting of the rail along the road that runs parallel to the river on the Pest side. They say "Rub it; believe me it is not rape" while explaining that rubbing the statue's legs would bring good luck. Also, they tell jokes to tourists about Charlie - the statue of a Hungarian police officer located in Zrínyi Street. Rubbing his belly makes one hungry and promises good food after the tour. During the summer, "he [the statue] stares at bare legs of women since they are in short skirts. That is his duty in the summer". If jokes fail, they try to re-fuse by following up with an apologetic statement, "That was a joke, you should laugh" which makes the tourists laugh even more. Indeed, akin to how James Clifford (1988) describes how we produce hybrid and creolized accounts of the world by conducting performances from "(re)collected pasts, drawing on foreign symbols and languages" (p. 15), tour guides like Zoltan engage in a performative bricolage (LéviStrauss 1962) by assembling (Latour 2005) and fusing symbols from different sources (Figure 4). 


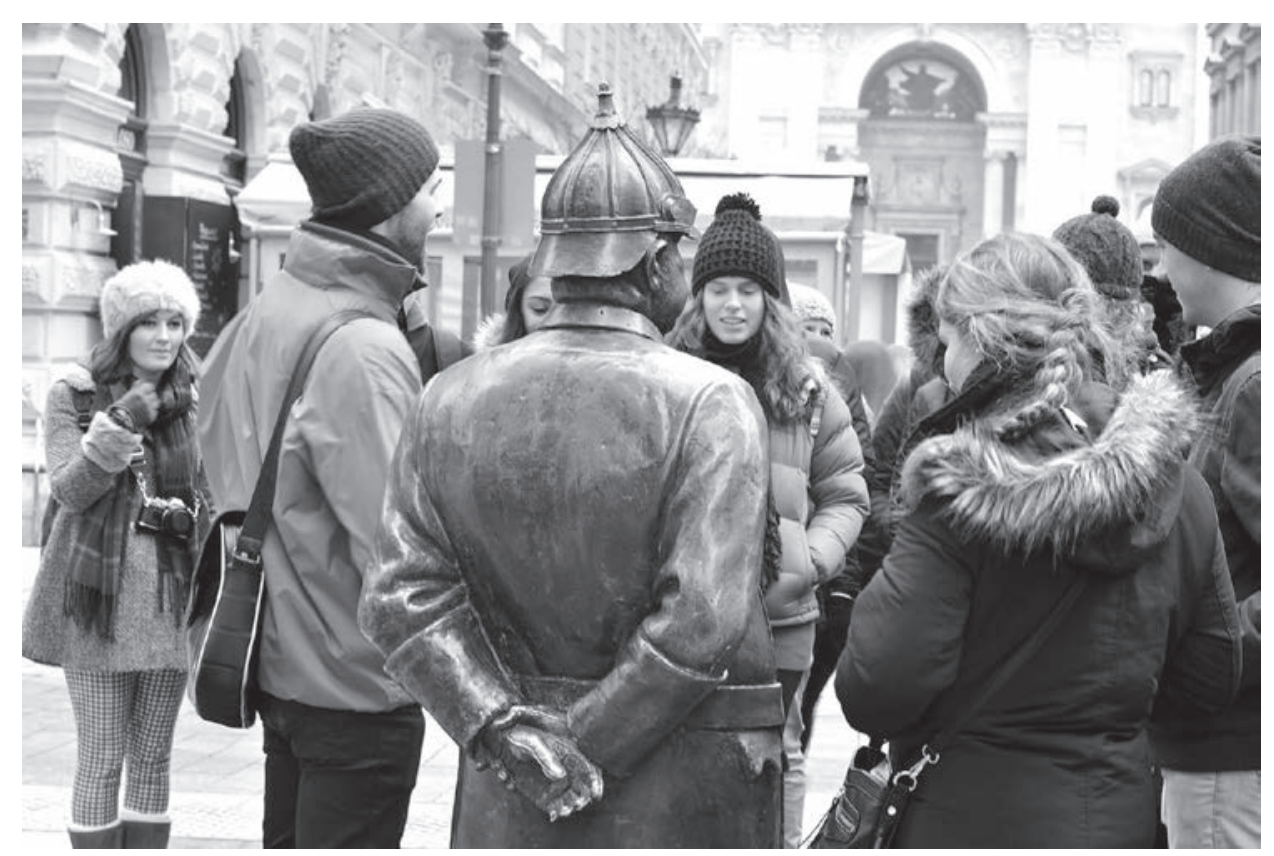

Figure 4: Zoltan describing Charlie to tourist. Photo by Saifullah Nasar, March 2015

\section{PERFORMING PHYSICALITY}

Aside from external/internal domestication and humor, spatiality and objects are also important aspects of free walking tours. Stories, or (re) produced narrations, are situated in the urban landscape though walking (de Certeau 1984) as a performance. The link between the external urban setting and the internal dynamic of the tour varies in relation to the, for example, tour type, weather or group profile. When analyzing these elements, we can divide them into fixed (i.e. the itinerary) and contingent ones. The latter includes such factors as the group profile, coordination with other guides who are doing the same tour at the same time and changes in the city infrastructure (e.g. traffic congestion, construction work, car accidents or protests). Their attempt at fostering spontaneity in their tours can be contested in different situations according to how they incorporate these factors into their script. Sometimes it could be due to simple reasons such as a sudden change in the location or the presence of loud noises that obstructs 
the narration. This happened once on one of the Jewish district walks with Orsi. Dohány synagogue has a sensitive alarm system that can be triggered easily when it detects any movement in the inner side of the fence. During the tour, the alarm was not turned off even after it was activated twice while we were standing in front of the cemetery. To make her narration audible, Orsi moved us to the memorial yard with a silver willow tree and continued with the story.

More complex decisions are made when guides need to pay attention to his/her colleagues who are doing the same tour to the same schedule. In such situations, decisions are made based on their script and familiarity with the guiding style of their colleague. For example, Judit tries to adjust her tour by taking into account several factors:

"In the summer...it can happen that there are five groups and we have to organize ourselves so that we don't bump into each other. So we have to pay attention to how long each one takes, how long my other colleagues take...but we don't make many big changes to the route but it can happen that we choose another street and we all end up at the same location because we have to show the same things. Like, we have to visit the St. Stephen Basilica. Of course, we must stop there... we all end up at the same place even if we choose another street to reach it...it comes with practice after a couple of years... as a trainee guide, you visit all the tour guides' tours so you see the different variations. How do they go somewhere, how do they stop and they tell you how many variations they have in mind. So, that's how you do that."

On one of our tours, our guide openly negotiated his time allocation in different locations. On that particular day, the group on the general walk was divided into two smaller ones. Our guide mentioned a few times that we need to move or else he would prolong his story because "we want to avoid my loudest colleague Zoltan". We met once, just before crossing the bridge to the Buda side, in front of the Academia building. Norbert (our guide) skipped the story about the building and joke about empty A, which Judit mentioned, and gave us a short lesson in Hungarian. We continued towards the Buda hill before the other group. As explained above, decisions made in these situations are based on a complex spectra of knowledge gathered 
through training and experience as a tour guide. This can be considered also as an improvisation based on the embodiment of the whole performance not just in space but also within the guides themselves. As such, the success of performative tourism is also anchored on how far a tour guide has been able to embody (Csordas 1990) the intimate rules and techniques of their activity (Figure 5).

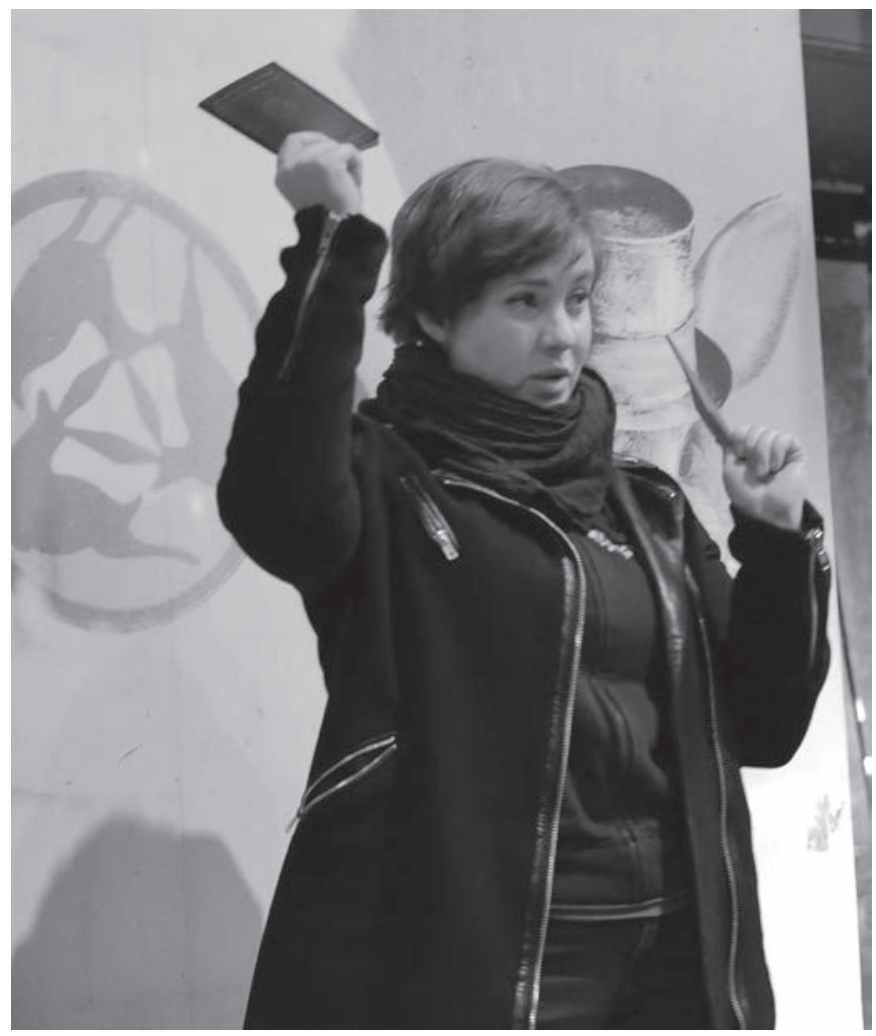

Figure 5: Nusi showing the blue and red passports to tourists in the Communism walk. Photo by Kristina Uzelac, March 2015

Another possible material reference on tours is the use of memorabilia. This is more apparent in the Communism Walk. This tour ends in one of the ruin pubs with a small exhibition and lecture about different topics from the communist period. Due to the different processes of forgetting and displacement, such as the spatial displacement of 
communist heritage to the Memento park, it is "hard to find connections between sites and stories" (Judit) during the communism walk. The invisibility of these physical references in the city's public space is compensated with a set of private memorabilia, which serve as pieces of evidence of everyday life during the communist regime. Stories about communism are re-embedded into those objects that are utilized as links to the past - passports (a blue one, a red one), photographs, postcards, badges, an employment booklet, maps (a world map without Australia and North America), old currencies, sculptures and Lenin's bust, which Nusi took from her grandparents' collection. Most of them are private collections taken by the guides from their family relatives, such as the employment and party booklet from Aron's grandfather, a blue passport for travelling to non-communist countries which belongs to the current boss of the company, or badges and books from Nusi's grandfather. Memorabilia forms part of the internal domestication of the story through which guides try to revive specific historical periods by "materializing" their authenticity through personalized stories and private objects. It allows them to discuss the communist past in more detail than that found on the streets and supports the authenticity of their narrations (Löfgren 1999:261). During the tour, they sometime extract particular signifiers from monuments and buildings as a cue for stories about communism. For example, when we reach the St. Stephen Basilica, nothing is said about the history of the building itself, but what it represents in very general terms, i. e. the spatial materialization of religion, was mentioned. As such, it serves as a starting point for a story about communism and religion. When we stop in front of the Health Agency, the narration shifts to discussing the quality of the communist health-care system and its problems. Sometimes, we enter some bars or buildings, and although they appear to be an improvised shelter during cold days, it is clear that they have agreements with the owner. This implies a functional network of agreement with different actors in the city (ruin pub managers, hotels - on Buda hill where the general tour ends, bars) which enables the undisturbed (or at least reduces potential breaks to the) flow of their performance (Figure 6). 


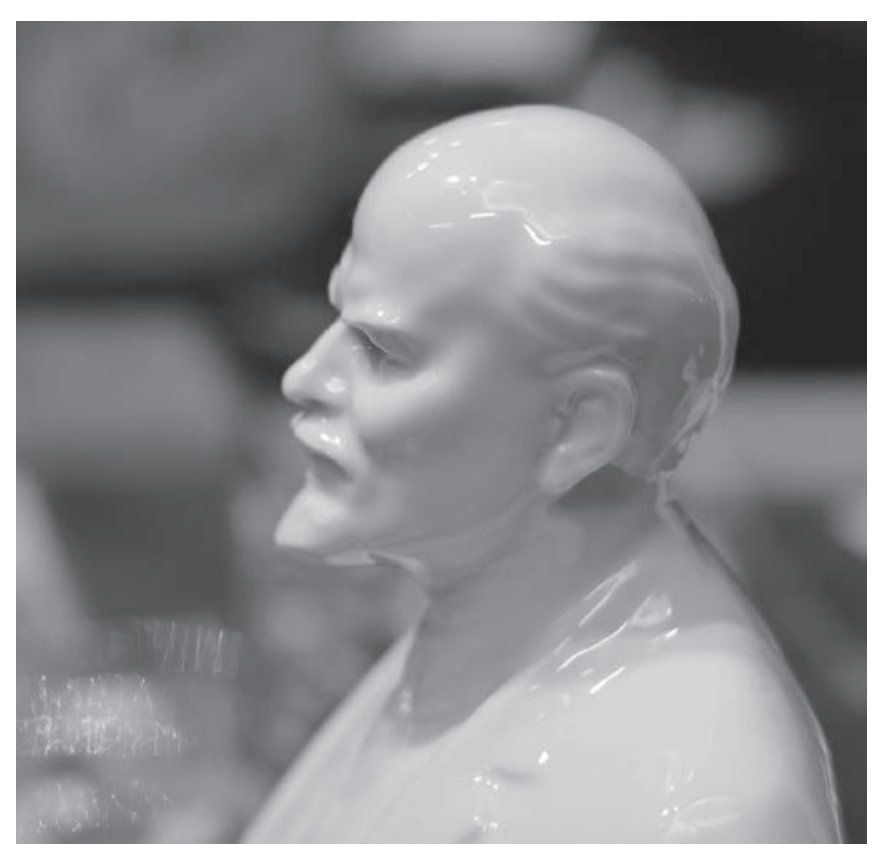

Figure 6: Lenin's bust is used as memorabilia in the Communism Walk. Photo by Macario B. Lacbawan Jr., March 2015

\section{CONCLUSION}

As described in the preceding discussion, tour guides perform by placing disparate elements of tours (i.e. a script, tourists, space, and the guide herself) into an integrated whole. The performance has to be authentic, easily decodable and capable of fusing the profile of the tourists with the history of specific sites. Otherwise, it becomes susceptible to challenges from tourists who can send "negative" feedback such as displaying "bored" gestures, or worse quitting the tour. On a more analytic level, this case is an interesting illustration of how memories are acted out, not simply as written texts but as on-going presentations, as memory in action.

However, there is an important caveat to our analysis. Had we also focused on tourists, it would have opened up new layers to the dynamics of performative tourism. This is because all the elements of a tour are integral - they form a loop where tourists are as active as tour guides. The 
off-stage account of tourist is missing - how do tourists prepare themselves before attending the tour? What are their thoughts following the tour's completion? How does one perform as a tourist? Furthermore, the symbolic role of power and ideology, including the continuity of performance in the tourists' off-stage cannot be discarded while giving an account of fusion and re-fusion. Aside from describing how tourists' measurable characteristics (e.g. age, gender, religion, nationality) impact the narration, a more fruitful analysis must also elaborate how tourists influence or regulate ongoing performances by contesting through other verbal and non-verbal means. This will disclose more about the power struggle between the two.

\section{REFERENCES}

ADLER, Judith. 1989. "Travel as Performed Art”. American Journal of Sociology 94/6:1366-1391.

ALEXANDER, Jeffrey, Bernhard GIESEN and Jason L. MAST. 2006. Social Performance: Symbolic Action, Cultural Pragmatics, and Ritual. Cambridge, UK: Cambridge University Press.

APPADURAI, Arjun. 1990. "Disjuncture and Difference in the Global Cultural Economy”. In Global Culture. Nationalism, Globalization and Modernity, ed. Mike Featherstone. London: Sage, 295-311.

BARTMANSKI, Dominik and Jeffrey ALEXANDER. 2011. "Materiality and Meaning in Social Life: Toward an Iconic Turn in Cultural Sociology". In Iconic Power. Materiality and Meaning in Social Life, ed. Jeffrey C. Alexander, Dominik Bartmanski, and Bernhard Giesen. New York: Palgrave Macmillan, 1-12.

BAUDRILLARD, Jean. 1994. Simulacra and Simulation. Ann Arbor, MI: University of Michigan Press.

BOURDIEU, Pierre. 1984. Distinction. London: Routledge.

CLIFFORD, James. 1988. The Predicament of Culture. Cambridge, MA: Harvard University Press.

CSORDAS, Thomas, J. 1990. "Embodiment as a Paradigm of Anthropology". Ethos 18/1: $5-47$.

CULLER, Jonathan. 1981. "Semiotics of Tourism". American Journal of Semiotics 1/1-2: $127-40$.

DEBORD, Guy. 1994. The Society of the Spectacle. New York: Zone Books.

De CERTEAU, Michel. 1984. The Practice of Everyday Life. Berkeley, CA: University California Press. 
EDENSOR, Tim. 2001. "Performing Tourism, Staging Tourism: (Re)producing Tourist SpaceandPractice”. Tourist Studies 1/1:59-81.DOI: 10.1177/146879760100100104

FRANKLIN, Adrian and Mike CRANG. 2001. "The trouble with tourism and travel theory?”. Tourism Studies 1/1: 5-22. DOI: 10.1177/146879760100100101

GADAMER, Hans-Georg. 1993. Truth and Method. London: Sheed \& Ward.

GARFINKEL, Harold. 1967. Studies in ethnomethodology. New Jersey: Prentice - Hall.

GOFFMAN, Ervin. 1959. The Presentation of Self in the Everyday Life. Garden City, NY: Doubleday Anchor.

HARVEY, David. 1990. The Condition of Postmodernity: An Enquiry into the Origins of Cultural Change. Cambridge, MA: Blackwell.

HARWOOD, Stephen and Dahlia EL-MANSTRLY, 2012. "The Performativity Turn in Tourism". University of Edinburgh Business School Working Paper Series 12/5: $1-18$.

LANGER, Beryl. 2004. “The Return of the Repressed: Alexander's Cultural Pragmatics". Thesis Eleven 79/1:43-52. DOI: 10.1177/0725513604046955

LATOUR, Bruno. 2005. Re-assembling the Social: An Introduction to Actor-Network Theory. Oxford, UK: Oxford University Press.

LÉVI-STRAUS, Claude. 1962. Le Pensée Sauvage. Paris: Librairie Plon.

LÖFGREN, Orvar. 1999. On Holiday. A History of Vacationing. Berkeley - Los Angeles - London: University of California Press.

PEIRCE, Charles S. 1998. The Essential Peirce: Selected Philosophical Writings 18931913, ed. by Nathan Houser and Christina Kloesel. Bloomington: India University Press.

URRY, John. 1990. The Tourist Gaze. London: Sage.

Thinking through Tourism: Annual Conference of the Association of Social Anthropologists, Metropolitan University London, $10^{\text {th }}-13^{\text {th }}$ April 2007. London: Association of Social Anthropologists (www.theasa.org/asa07). 
Kristina Uzelac

Saifullah Nasar

Macario B. Lacbawan ml.

\section{“OVO JE TREBALO BITI SMIJEŠNO - ZAŠTO SE NE SMIJETE!" - IZVOĐENJE POVIJESTI I TURISTIČKE ŠETNJE U BUDIMPEŠTI}

Performativni obrat $u$ društvenim znanostima obuhvatio je i studije o turizmu koji se u tom kontekstu promatra kao izvedbeni process. Dosadašnje studije ukazuju na određena ograničenja ovoga pristupa. Fundamentalna kritika dramaturškog pogleda jest da izvedbenost ne promatra kao niz pojavnih društvenih procesa. Na primjeru besplatnih turističkih šetnji (free walking tours) u Budimpešti, u članku se analizira turizam kao izvedbeni čin koji se realizira kombiniranjem dominantnih kulturnih kodova, upotrebom predmeta te humorom. Realiziran je kao pokušaj spajanja različitih elemenata u dramaturšku prezentaciju. U članku se raspravlja slijedećih pet elemenata izvedbe turističkih vodičanjihova interakcija sa publikom/turistima, prethodna iskustva, upotreba kulturnih kodova, svakodnevica predmeta čije se simbolika koristi u prezentaciji te poigravanje sa jezičnim formama kroz humor. U zaključku predlažemo nekoliko dimenzija koje se mogu uključiti u daljnja promišljanja i rasprave o turizmu kao izvedbenom fenomenu.

Ključne riječi: performativnost, izvedba, dramaturgija, sjećanje, humor, materijalnost, turističke šetnje, Budimpešta 